\title{
PROFILES OF BURGLARS IN TURKEY AND SOME FACTORS IN THE PROCESS OF CRIMINALIZATION
}

\author{
Türkiye’de Ev Hırsızlı̆̆ Suçunu Işsleyenlerin Profili ve Bireylerin Kriminalleşmelerinde \\ Etkili Olan Bazı Faktörler
}

\section{Rıfat BİLGIN ${ }^{1}$}

\begin{abstract}
The topic of this study is people who committed the crime of burglary. The goal of the research is to determine the profiles of people who committed the crime of burglary and to present some factors that affect the emergence of individuals' criminal tendencies. The research was carried out on 50 criminals in Diyarbakır closed prison because of the crime of burglary. The research is based on the interpretation of data and findings obtained from the survey forms conducted on the prisoners in scope of the study and detailed interviews that were held with them. The obtained findings show that some effects, such as having low socioeconomic position, existence of some family problems, working on streets at early ages, contacting with children on streets that commit crime and have delinquent actions, existence of the potential of associating with criminals, using drugs, leaving school and imitating older criminals, are effective in individuals' becoming criminals.
\end{abstract}

Key Words: household burglary, profiles of criminals, crime factors, Turkey/Diyarbakır

\section{ÖZET}

$\mathrm{Bu}$ çalışmanın konusunu, ev hırsızlığı suçunu işleyenler oluşturmaktadır. Araştırmanın amacı; ev hırsızlık suçunu işleyenlerin profillerini saptamak ve bireylerin kriminal eğilimlerinin oluşmasında etkili olan bazı faktörleri ortaya koymaktır. Araştırma, Diyarbakır ilinde bulunan kapalı cezaevinde ev hırsızlığı suçundan tutuklu ve hükümlü bulunan 50 suçlu üzerinde gerçekleştirilmiştir. Araştırma, çalışma kapsamındaki suçlulara uygulanan anket formundan ve onlarla yapılan derinlemesine görüşmelerden elde edilen veriler ve bulguların yorumlanmasına dayanmaktadır. Elde edilen bulgular bireylerin kriminalleşmelerinde veya suça başlamalarında; düşük sosyo-ekonomik pozisyona sahip olma, bazı ailesel sorunların varlığı, küçük yaşlarda sokaklarda ücret getirici işlerde çalışma, sokak ve mahallede suç ve sapkın eylemler sergileyen çocuklarla temas etme, birliktelik oluşturma olanaklarının varlığı, uyuşturucu madde kullanma, okulu terk etme ve kendilerinden yaşça büyük olan suçlulara olan özenti duyma gibi bazı faktörlerin etkili olduğunu ortaya koymuştur.

Anahtar kelimler: Ev hırsızlık suçu, suçluların profili, suç faktörleri Türkiye/Diyarbakır

\section{INTRODUCTION}

The crime of burglary is one of the significant crimes based on the commitment frequency. So, this crime type affects a high amount of population. Throughout Turkey, a significant amount of crimes that are reported to the police is burglary. For instance in Turkey in 2012, 1,491,769 public safety incidents took place. Thievery constituted 405,405 of these crimes. Thus, $27 \%$, in other words one fourth of the public safety violations were the acts of larceny. The figures on the frequency of the crime of theft in Turkey between the years of 2007 and 2012 are as follows: In 2007, 294,972: in 2008, 256,562; in 2009, 304,570; in 2010 351,838; and in 2012, 405,405 occurrences of the offence were recorded. As the figures demonstrate, a serious increase in the frequency could be observed (Polat et al., 2013: 5).

This study was carried out in Diyarbakir city center in Turkey. A significant aspect of the city of Diyarbakır, in which the research was carried out, is that it is in Southeastern Anatolia region and it is one of the important cities in which mostly Kurdish people live. It can be said that, this

\footnotetext{
${ }^{1}$ Yrd. Doç. Dr., Frrat Üniversitesi İktisadi ve İdari Bilimler Fakültesi Sosyal Hizmet Bölümü, rifatbilgin@gmail.com

${ }^{2}$ Prof. Dr., Firat Üniversitesi, İnsani ve Sosyal Bilimler Fakültesi Sosyoloji Bölümü, ELAZIĞ zkizmaz@,firat.edu.tr
} 


\section{F.Ü. Sosyal Bilimler Dergisi 2015-25/1}

city is negatively affected from the process of struggle with PKK terror organization. Diyarbakır, one of the densely populated cities of Southeastern Anatolia region, has been going through a radical change and transformation process especially after 1990s. The most important reason of this transformation is the developments related to Kurdish problem. With the increase in armed actions of PKK, the style of government's intervening in this process and difficulties have been very effective on lifestyles of region's people.

Diyarbakır is one of the cities that have the biggest problem of poverty and reflections of this problem in daily life are relatively dramatic. Cities in Eastern and Southeastern Anatolia regions are at the bottom lines according to various human development indexes; average annual income per capita in the region is almost equal to one third of Turkey average.

According to Turkish Statistical Institute's (TUIK) findings for 2013, Diyarbakir is the third lowest province in employment rate in Turkey. Likewise, Diyarbakir is the $5^{\text {th }}$ province based on the unemployment rate.

As per 2011 census, the population living in central Diyarbakir was 875,069 (TUIK, 2011). Total population of the province was 1,570,943 according to TUIK 2011 census. While Diyarbakir city center's population was 309.940 in 1985 , this number increased to 381.144 in 1990. In 2007, city population was determined to be 855.389 . During the years of 1990-2000, yearly population increase was $21,73 \%_{0}$ and above Turkey's average of $18,3 \%$. In Diyarbakır, urbanization rate in 2000 was \%60; in 2007, this number was determined to be approximately \%64. One of the important reasons of high increase in the population of Diyarbakır city center is migration.

The percentage of the young population is quite high in Diyarbakir province. In 2013, the fact that in $2013,56 \%$ of the population of the province was under the age of 25 was a very significant fact (TUIK, 2013). On the other hand, in the past, Diyarbakır drew attention as it was one of the cities that had the highest children labor problem resulting from some problems such as migration, unemployment and poverty. Household in very small and crowded and unhealthy houses sometimes live off through the money earned by their children. However, as this study would demonstrate below, the fact that certain youth work on the streets had an effect on their criminalization.

As a result, the struggle environment in the region that has been continuing for 25 years destroyed socio-cultural texture of the region and Diyarbakır and seriously damaged economic structure. In this frame, big amount of migration, increase in unemployment, and poverty, child labor abuse, crash of socio-cultural values, the structure of the city that direct children to crime and high amount of crimes have been the significant negative points that attract attention in the process of struggle with PKK.

\section{THEORETICAL BACKGROUND}

The crime of theft is defined in New Turkish Criminal Law (Article 141) as, "the illegal taking of another person's property without that person's freely given consent in order to provide benefit for oneself or for another person" and individuals that commit this crime are to be punished for an amount of time varying from 1 to 3 years. But according to the same law's $61^{\text {st }}$ article, judge can determine the lower and upper limit punishment by taking some factors into consideration such as; style of crime, tools used in crime, significance and value of crime, severity of the damage, intenseness of offender's intention, purpose and motive (see. Özgenç, 2005:871- 879; Uğurlu, 2010:199-201).

The crime of burglary is generally committed with the motives of economic gains. This is why, it can be said that economic factors are more significant in committing this crime (bkz. Kizmaz and Bilgin). Another concept that becomes prominent in this process is the concept of "opportunity"; this is why, concepts of "opportunity" and "interest" has a central importance in crime. In this sense, individuals that have the potential to commit this crime are affected by the existence of the 
opportunities and attracting advantages. In this frame, ensuring that the interest that will be gained by burglary is more difficult and risky; so, making aforementioned opportunities more difficult or completely removing them will surely decrease committing the crime of burglary.

Crime of burglary and individuals who commit this crime are generally discussed in terms of sociologic crime theories that focus on criminal motivation and opportunity theories (such as rational choice, defendable environment and routine theories) that focus on environmental factors and victims. As this study focuses mostly on the features of criminals and factors that affect shaping of their criminal structures, criminals were attempted to be analyzed in the frame of theories based on criminal motivations. Sociologic crime theories focus on social factors and processes, which affect individuals' criminalization can be defined as; insufficient social organizations, strain, sub-culture, social control and social learning theories. These theories answer the question of "Why do individuals commit crime?" So, a significant aspect of these theories is that they put criminal into the center. In here, the topics of "Which factors are used while analyzing the concept of crime?" and "How is a crime analyzed?" in these theories will be touched briefly. The theory of having insufficient social organizations states that factors of poverty, heterogenic culture, and physical mobility cause social disintegration and weaken individuals' bonds with social values and this situation affects the criminalization process of individuals (See. Ellis and Walsh, 2000:354; Vito and Holmes, 1994: 143; Bohm, 1997: 7). Sampson et al. (1997), stated, in their study on reviewing having insufficient social organizations theory, that population mobility, migration density and disadvantageousness level (socio-economic level, family problems etc.) cause deformation in social structure and this deformation not only weakens traditional and informal control mechanisms, but also weakens social trust and structure of social togetherness and finally all of these cause crimes.

Strain theory, firstly formulized by Merton, presumes that crimes emerge when individuals at lower classes in classified societies try to reach goals through illegal ways or techniques as their opportunities are limited or obstructed. In a sense, strain theory explains crime as a result of the fact that individuals, who live in societies in which social structure is not just or equal, don't have equal opportunities (Adler et. al., 1995:111). When looked from social strain perspective, it can be seen that mostly individuals who have disadvantageous positions socio-economically and culturally commit crimes. This means that strain theory accepts criminality as a phenomenon of lower class rather than higher class. According to strain theories, people of lower classes have limited opportunities to become a higher class member or they are obstructed; and as these culturally disadvantageous people don't have the chance to reach their cultural goals through legal ways, they try illegal ways to reach them.

Crime sub-culture theories assume that life, value and codes about crime are different from the general cultural structure of society and individuals' socialization through these values and codes transform them into criminals. Here, criminal life styles, especially experienced through gangs or crime groups, are very important. Similarly, pioneers of these theories focus on structure that rationalize crime (Matza and Sykes, 1957) and structure that perceive crime as a desired normal behavior (Cloward and Ohlin, 1960; Cohen, 1955).

Cohen, who discusses the phenomenon of crime in terms of sub-culture, states in his famous work named "Delinquent Boys", (1955) that, crime sub-culture emerges as a result of the struggle between low and middle class culture. According to him, children of low class try to reach the goals and lifestyles of children of middle class. But reaching these goals is very difficult for low class children because of their class and economic situations, so this situation creates a "status frustration" in individuals; and -according to Cohen- all these cause children lose self-trust and reaction. This is why; Cohen believes that crime sub-culture is resulted from this reaction against values and norms of middle class. According to him, schools are the places where these reactions and contradictions can be seen. It is stated that failures of children of low classes resulting from their inability to be successful at school or their weak communication skills cause formation of 


\section{F.Ü. Sosyal Bilimler Dergisi 2015-25/1}

gangs -accordingly, criminalization-.

Another culture theorist Miller, who discusses the phenomenon of crime in sub-cultural frame, states that child crime is resulted from the fact that there are cultural factors about crimes in the value systems of lower classes; namely, crime is not developed as a reaction to middle class value systems. In other words, according to Miller, crime is a result of rooted values and norms special to low class.

On the other hand, social control theory explains crime as; weakening of bonds with traditional values and institutions such as family, school, religion and friends. According to Hirschi, strong bonds with traditional values and institutions such as family, school, religion and friends decrease their possibility to commit crime. Similarly, this possibility increases if there is a weak bond between aforementioned values (Hirschi, 1969). Social learning theory also sees crime as a process of learning acquired in the frame of interaction of individuals. One of the pioneers of learning theory, Sutherland (1947), states that crime is resulted from the contact of an individual with criminal values and norms; in other words, it is a behavior learned in the process of a social interaction with criminal peers. But the significant point in here is the level and feature of these contacts. As a result, sociologic crime theories discuss crime in terms of social structure, social change, socialization and culture.

During the recent years, studies focused on the crime of burglary were integrated models usually formed by piecing together several theories. In other words, instead of a single focus on micro or macro level processes, it has been strikingly observed that, a tendency to create a multilevel framework became prominent. For instance in their study, Miethe and McDowall (1993) utilized a model formed with the association of the theories of routine activities/life styles highlighting the importance of criminal opportunities and the theory of social disorganization stressing the social control element related to ecological context. This study would consider the criminals, in the same manner, in the framework of several theories such as; social disorganization focusing on the reasons of individuals' criminal motivations, social strain, social control, social learning and sub-culture. Thus, the reasons underlying individuals' criminal tendencies were studied in the context of the variables and perspectives of migration/settlement mobility (social disorganization theory), the effects of family structure and effect of delinquent peers (social learning theory), the decline of family functions, inadequate and insufficient socialization and weakening of traditional values (social control theory), poverty/unemployment (social strain theory), and socialization of individuals around crime values/culture (sub-cultures theory).

\section{METHODOLOGY OF THE RESEARCH}

\subsection{The problem of research}

It was observed that in Diyarbakır, where the study was carried out, crime of burglary is a significant problem. During the interviews held with people who live in this city, it was found out that the crime of burglary creates a serious nervousness in society and individuals give effort to deal with this problem. It was seriously felt that there is a big fear for crime, especially for burglary. So the existence of some serious negative effects such as common household burglary, fear of society caused by crime gangs, serious nervousness about security and the high risk ratio of being victim necessitated the research of this issue.

The perception of distrust created by burglary crimes in Diyarbakır, created a very big problem for people living in that city. Determination of criminalization risk factors, specification of features of individuals who commit the crime of burglary and determination of dynamics of the crime of burglary in Diyarbakır are very important.

The reason why this research was carried out in Diyarbakır was that the city has the dynamics of criminalization which has been caused especially by many negative developments after 1990s. After 1990s, Diyarbakır has been exposed to migrations from neighbor cities and rural areas 
resulted from struggles with PKK. The city had to face with many economic, political and cultural problems after these migrations which probably doubled the population. It is stated that after 1990s, as a result of migration or displacement policies, minimum 400-500 thousand people have come to this city. Some of the significant problems resulted from this situation are especially economic problems such as unemployment and poverty, problem of children working on streets, dramatic increases in the number of divorces and domestic violence, weakening of social capital and increase in social violence.

An important reason why Diyarbakır city was chosen as the population in this research is that this city is mostly associated with crime; there has been news about exporting criminals to other cities and kidnapping children in order to use crime gangs in Turkish media. In the past years, the city was generally associated with migration, poverty, unemployment, anomaly and crimes which are the basic problems analyzed in this research. In this frame, we can say that there is not a scientific study about the crime of burglary in Diyarbakır, and this fact is a significant reason of this research. This is why; it is significant to determine the profiles of burglars and criminalization dynamics in Diyarbakır.

\subsection{Subject and Objectives of the Research}

The subject of this study is the crime of burglary in Diyarbakır city center. In the content of this study, there are the issues of researching some topics such as profiles of criminals who committed the crime of burglary and the dynamics of this crime. In this frame, issues such as criminals who committed the crime of burglary, factors affecting criminalization of individuals, the reasons of these crimes and preventing this crime will be discussed. The goal of the research is to understand criminalization of individuals or the process of transformation into criminals and determine sociologic dynamics affecting individuals' tendency towards crime.

The study aimed to determine the following issues concerning the criminals:

1. Socio-demographic and economic profiles of criminals (such as gender, family structures, marital status, migration and residence status, level of income),

2. The factors effective in criminalization of the individuals (familial factors, economic factors such as poverty and unemployment, factors related to working the streets, effect of peer structure, existence of sub-culture, criminal aspirations, development of substance abuse and interactions with crime organizations),

3. Factors related to criminal career and criminal progress (age of delinquency, the nature of first offense, perpetration frequency, changes in the nature of offense, concentration or alleviation of offenses).

Thus, the questions directed both in informal interviews and in the questionnaire form aimed to provide an understanding on the issues depicted above. In this context, the questions in the survey form were chosen among the ones, which could be formulated in multiple choice or do not necessitate extensive deliberation, while in the interview scale, the questions allowed deliberation on the criminalization stories of the criminals and the stages of their criminal progress.

\subsection{Population and Samples of the Research}

This research was carried out on imprisoned or sentenced criminals in Diyarbakır E-Class Prison because of the crime of burglary. There were 65 inmates in the prison for burglary during the time of the study, however only 50 convicts participated in the study. The reason for limiting the study with only 50 participants was the fact that, certain inmates had refused our request for an interview and some others, who had accepted our request but terminated due to their refusal to answer the questions in sincerity. Thus, 15 convicts had to be excluded from the study.

Both detailed interviews were made with these criminals and survey forms were conducted on them. In order to determine which variables are effective in terms of leading them towards crime, many questions were asked such as; the types of family problems they had, their family's economic 


\section{F.Ü. Sosyal Bilimler Dergisi 2015-25/1}

level, at which age they started committing crimes, formation of their criminal tendencies, their relations with alcohol/drugs, frequency of going into prison, structure of criminal peer groups and problems they had during school.

Initially the list of the criminals to be interviewed was obtained from the prison management and then a space was secured, where the interviews would take place and no other than the researcher would be admitted. Finally, volunteers among the convicts on the list were brought to the interview room in an orderly fashion. Two researchers recorded the interviews and filled out the survey, face to face with the subjects.

The subjects who replied to our request for interview were called upon. Likewise, the limited number of interviews with convicts who refused to answer certain questions during the interview, although they had initially volunteered, were terminated in consideration of their criminal tendencies. Thus it could be argued that the study was conducted with criminals who had volunteered.

\section{RESEARCH FINDINGS}

All of the criminals, with whom the interviews were made, were male. Most of the criminals started committing crimes at very early ages; $\% 84$ of criminals stated that they started committing crimes at 15 or before. Places that most of the criminals lived were generally areas where poor or low-income families live.

When incomes of criminals' families were analyzed, it was seen that they generally had low income. $\% 62$ of criminals stated that their monthly income was less than 1000 TL. There were no criminal who stated that his father's income was more than 2000 TL. Similarly, when criminals' family jobs were analyzed, it was seen that their fathers generally were working at low-grade jobs (shopkeeper \%32, day-laborer \%28). Only 4 criminals stated that their fathers were "civil servants". The rest of the criminals stated that their fathers were "farmers", "retired people", and "workers in state enterprises". Similarly, almost all of the criminals (\%94) stated that their mothers did not have jobs, they were housewives. Only three criminals said that their mothers were working at paid jobs (low-grade jobs such as such as cleaning).

Another important feature of criminals is that they had a low level of education; \%24 of criminals was graduated from primary education and $\% 10$ had no education. Only $\% 10$ of criminals was graduated from high school; most of the criminals dropped out. \%66 of criminals was dismissed from schools because of various reasons. Most of these individuals were dismissed from schools during the first and second stages of primary education (\%67). Among the reasons why they were dismissed from school, there were burglary, breaking disciplinary rules, involving in fighting/injuring, absence or being unsuccessful at school.

One other significant finding about the profiles of criminals, with whom the interviews were made, was that they started committing crimes at very early ages. Almost $\% 85$ of criminals stated they when they started committing crimes, they were under 16. When age categories in terms of committing crimes were analyzed, it was determined that, burglary was mostly committed at the age of 14; 15, 12 and 13 age categories respectively followed that age. But except 9 criminals (\%18), all of the criminals stated that they hadn't get caught in their actions.

$\% 32$ of criminals stated that their families migrated from where they live and added that migration was resulted from security reasons especially during 1990s because of the struggle with PKK terror organization. It was determined that the areas in Diyarbakır that allowed immigrants were the places where act of violence occurred more. This means that forced migration or displacement is one of the significant factors that increase crime potential in Diyarbakır. It can be said that settlement mobility and low socio-economic statue destroyed social fabric and organizational level and this increased crime and criminality ratio. This is why, the phenomenon of criminality in Diyarbakır were directly related to displacement and a deep poverty problem. 
Settlements where families that have low-income live and places where let immigrants in generally have crime low-culture elements or criminality values. These settlements where informal values and control weakened can be classified as disorganized places. According to the population of this research, Streets are the places where children socialize, in other words, children of the families living in these places spend an important amount of their time on streets. But streets don't only mean "game" for these children; they also have to earn money on streets; \%74 of these children stated that they started working on streets starting from very early ages (selling bagels, sunflower seeds, gums, tissues etc. or polishing shoes). Low income levels of families or economic problems are very important factors that force children work on streets.

An important reason why children work on streets or the problem of child labor is that parents don't have jobs. In here, child labor is seen as the living strategy as an alternative factor. As mentioned by Yükseker, problem of children working on streets emerges as a manifestation of urban poverty. Besides unemployment, having sick or old father, weak relations with family are the other factors that affect children work on streets (Yükseker, 2006 p:227).

Children that spend a lot of time on streets contact with sub-cultural values and criminalize in time. It is difficult for parents to control their children who work on streets or protect them from the risks of streets.

Another factor that was determined to be effective in criminalization of children is that they imitate criminals that they meet on streets. Among the responses given to a question asked to the convicts on the beginnings of their criminal career or a criminal individual, the concept of "criminal aspiration" was prominent. A few quotes by the criminals on the issue are depicted below:

"I started stealing after I began to hang out with old thieves in my neighborhood. I started to steal with them. The reason I started to hang out with them was the cars they rode, the clothes they wore and the aspiration for the money they had in me. When we saw them riding their cars on the street we started to aspire them. Even their clothes were designer brands." (K.Y.)

"Aspiration was the most effective reason in why I became a thief. The car certain people drove, the clothes they wore, the money they had and the lives they lived was attractive to me and others. It was also nice to see they earned easy money." (M.T.).

(M.T.) "In the neighborhood, the attire of criminals, thieves, the money they have attracts people. I cannot even afford clothes like him even if I have a job.” (M.K.)

Generally, criminal individuals seem rich and powerful on streets and this affect children working on streets with very low incomes and they start to have tendency towards crime. Criminals in this study stated that older criminals that they met had beautiful cars, clothes, cell-phones, a lot of money and they seemed to be very content with their lives; so they were affected from all these and started to have tendency towards crime. In the light of this information, it was determined that opportunities that criminals had and their images create a big desire and hunger for working together with criminals and commit crime. These children who start imitating these criminals think that they will have the same opportunities in time if they work together with them. This is why; images of criminals on streets are very encouraging for children; after all, most of the criminals stated that they started committing crimes firstly because of their pretension.

Findings determined in this research about the families of criminals can be summarized as such; \%82 of criminals' families were made of 5 or more individuals and they stayed in the same place; similarly $\% 34$ of criminals had 4 or more siblings and $\% 54$ of these criminals had 7 or more siblings. These findings show that criminals had a crowded family structure and many siblings.

All of these criminals -except one- stated that they were single when they started committing burglary (\%98). It was determined that, during this study only 4 of the criminals were married. $\% 12$ of criminals ( 6 criminals) said that they had been living separated from their families, and 


\section{F.Ü. Sosyal Bilimler Dergisi 2015-25/1}

$\% 10$ of them ( 5 criminals) said that their father had died. When ratios of these two situations were evaluated together, it was seen that $\% 22$ of criminals had a history of broken families.

The question: "Did your family or family members affect your becoming criminal?" was asked to criminals and $\% 44$ stated that "yes, they did" while \%66 said "no, they didn't". This ratio can be interpreted as; approximately 4 of 10 criminals think that their families are responsible for their current situation. Criminals, who stated that their families were responsible, stated that; fathers $/ \% 43)$, siblings and elder brothers (\%24) and cousins (\%23) were effective in their criminalization. The ones that mentioned their fathers' effect emphasized "the fact that their father is criminal" and "they were subjected to violence". The ones that mentioned their "siblings" and "cousins" stated that the fact that they were using alcohol and drugs, they had gambling habits and their criminal acts had effects on them.

One significant factor that was discussed in the frame of violence and family relation was determining if there was another criminal in criminal's family. Some criminals discussed the effects of criminal family members in their transforming into criminals. $\% 32$ of criminals who committed the crime of burglary stated that there were criminal individual/individuals (father and siblings) in their family, which is a very important point that should be taken into consideration as it is a very strong risk factor for becoming a criminal. Especially in social learning theory, close contact with criminals is thought to have impact on becoming criminal. Criminals said that generally their family members had committed the crimes of burglary, injury and drug. Existence of a criminal in family - especially father- can be an important reason in the development of criminal tendency.

Another finding about criminals' families is the ratio about the fact that they do not go to their houses regularly. \%66 of criminals stated that they "mostly" hadn't gone to their house while \%20 of them said that they "sometimes" hadn't gone. Only \%14 of them said that they regularly had gone to their house. \%56.5 of them stated that the reason why they hadn't gone home is that they had started committing crime. Other criminals said that the reasons why they hadn't gone home are; problems, fights and tension between parents, divorced parents and harsh behaviors towards them.

On the other hand, $\% 44$ of criminals stated that they left heir houses before they were put into prison. When these findings were evaluated with other data, it can be said that individuals avoid going to house and because of this, they are out of their families' control. There can be a relation between being out-of-control of families and committing crime or it can be said that being out of control eases committing crime.

There are some reasons why criminals don't go home regularly. When the issues pointed by criminals on this topic were evaluated, it was seen that some of them emphasized problems in their families; some told that they wanted to be away from house because of possible quarrels about their crimes, and some of them stated that they wanted to avoid intervention of their parents who want to prevent them committing crimes. Similarly, individuals who rob houses at night can not go to their houses regularly. It is a fact that families don't let their children go out of their houses whenever they want. This is why; criminals do not want to stay at home with their families or do no go home regularly in order to continue their relations with other criminals and continue their pleasure-based life styles and criminal behaviors, in order to go out of town when they want to steal something or to commit some other crimes, and in order run away from security forces. Especially some recognized criminals prefer staying at some unknown places rather than staying with their families as they want to prevent being taken into custody because of every crime of burglary (whether or not they committed that crime).

As a result of the fact that criminals do not go home regularly, they don't see their family members often which cause families not being aware of their children's criminal behaviors. In the 
interviews, most of the criminals stated that their families hadn't known what they had done until they were taken into custody or arrested, which proves the aforementioned fact.

One of the factors that attract attention about the formation of individuals' criminal tendencies is the "peer effect". \%38 of criminals said that their friends were criminals just like them. Similarly, \%94 of individuals who committed the crime of burglary stated that they had committed crimes "with their friends". These ratios about friend or peer effect are very significant. During informal interviews, most of the answers to the question of how they started criminal acts were determined to be related with criminals' contacts and interactions with their peers or friend groups. This effect continues not only at the beginning of criminal acts, but also when the criminal continues his criminal acts. In this frame, it is possible to say that criminal behavior emerges through the interaction with friends or peers and in the context of groups. Criminal sub-culture in peers' or friends' environments creates motivational or intensifier resources for criminal behaviors. In this frame, these environments have the function of teaching criminal behaviors and rationalizing crime. Similarly, through peer relation, individuals socialize around criminal values which cause them start and continue crime. Generally, children who have such friends are the ones who have some problems with/in their families. On the other hand, some children who don't find enough attention or love in their family prefer such peer groups as the resource of a new interest and statue. This research transforms them into criminals.

In the interviews, questions of "how did they start the crime of burglary" and "how do they explain their being criminal individuals" were asked to the criminals, and most of them said that they wanted to imitate their "friend groups" or "people they know on the streets". When their explanations about the issue were analyzed, it was understood that they had started burglary because of their friends or people they know from neighborhood. Criminals mentioned that, in their neighborhood, there were many children who were committing the crime of burglary often; everybody knew these criminal people and children wanted to imitate them. They said that lives of these criminals were interesting and attractive for them and it was not difficult to work together with them. Here, it is understood that in the center of the formation of tendency to commit crime, there was pretension. At the bottom of this pretension, there was the idea of lifestyle and statue that will be acquired with the money that will be gained through burglary.

In the interviews made with criminals in scope of this research, the question of "What kind of features do criminals' friends have" was asked. Most of the criminals stated that their friends were poor, migrated, had problematic families and some of them had divorced parents. Similarly, these criminals put forward that having these features lead individuals towards crime. An important reason of this tendency is that because of these aforementioned features, individuals have weak communication with their families and in their house; migration is also a significant factor in this tendency as it weakens social connection. Children, who work on streets because of economic or cultural factors, are affected from other criminals. Individuals who don't get any financial help from their parents want to buy bicycles, computers and cell phones etc. and as it is not possible for these individuals to reach them, they start to find some illegal ways especially with the effect of their friends; they think that they can have their dreams through burglary. In the light of the points that criminals mentioned, it was determined that the need for money, because of poverty of some other reasons, is the basic motivation of burglary.

Another significant determination about criminals is the findings about frequency of drug use. Almost all of the criminals (\%98) stated that they had used drugs before they went into prison. \%34 of criminals said that they had used drugs or some other chemicals that increase courage while committing crime. It was determined that while some criminals had started using drugs before they committed the crime of burglary, some of them started taking drugs after they had committed crime. The ones in the first group stated that they firstly started taking drugs when they were with their friends because of desire or pretension, then they needed money in order to continue taking drugs so they started committing crime in order to find that money. The ones who stated that they 


\section{F.Ü. Sosyal Bilimler Dergisi 2015-25/1}

used drugs after committing crime stated that they used drugs as they increased their courage and gave them joy. Seddon emphasizes three approaches about the relation between drug use and crime: 1 . Using drugs cause committing crime, 2. Committing crime causes drug use, 3. Relation between crime and drugs are also related with some other factors (sex, being young etc.) (Seddon, 2000: 96).

The significant point in here is that there is a close relation between the crime of burglary and narcotic crimes. Apart from that, it can be said that alcohol (\%38 often, \%44 sometimes) and drug use have an accelerating and facilitator effect on committing crime. What criminals told about drug use show that alcohol and drug use are significant components of criminal lifestyle. On the other hand, the use of drugs or alcohol by most of the criminals is a significant criterion that determines the frequency and violence of crime. Another finding of the research is that generally criminals started using drugs at very early ages.

Most of the criminals with whom the interviews were held said that in Diyarbakır, especially smoking marijuana is very common and it is very easy to find it. Some of these criminals stated that had they started smoking marijuana when they were with their friends and they had committed crimes in order to find money for buying marijuana. Based on the explanations of criminals, it was determined that factors such as pretension, tension created with the life of crime and decreasing pressure, gaining courage and searching for excitement were important in the development of drug use.

Diyarbakır, which is the city of this research, has attracted attention in terms of not only excessive number of criminals in the city, but also in terms of children that are used in the city for criminal activities and brought to other cities in order to commit crimes. In the interviews the question of "How are the children kept by gangs in order to be used in crimes or how are they used in criminal activities?" were asked to criminals, and they said that they could easily find children in order to use in criminal acts; in addition to that, crime gangs don't take every children into their gangs. Some of the criminals said that while some families rented their children, most children were either volunteers or taken into gang by force, and once they were kept by gang members, they weren't allowed to go away and sometimes they were tortured. On the other hand, a significant result of the research was the determination of the fact that kidnapping and renting children decreased when compared to the past.

Starting from the points mentioned by criminals, it was understood that crime gangs were looking for some specific aspects in children. Based on the interviews with criminals, these features were determined to be searched by crime gangs:

1. Features of children's families: Gangs generally choose children of poor, divorced families who don't have courage or power to resist gangs. It can be said that children of such families are taken easily into gangs and they are used in criminal acts.

2. Features of individuals: Gangs generally prefer children who want to imitate criminals and who have ability. It is determined that -although rarely- crime gangs fight with one another for skillful and courageous children. In other words, crime gangs follow "good kids" who have problematic families, who already started committing crime and proven themselves as criminals. "Good kid" means fast, skillful, overbold child who can climb easily, can bring money and doesn't speak if arrested.

Children who start committing crimes like apprentices under the protection of experienced and older criminals advance in their carries and get experience. These children who start committing crimes as apprentices have to be successful and behave trustworthy in order to gain trust and appreciation of their "masters". Being successful is closely connected with; their willingness for committing crime, being quick, intelligent, reliable, skilful enough not to be caught, not snitching friends, being planned and good runner. 
Another significant point determined by the research is that most of the criminals often committed crimes and they had gone into prison more than once. $\% 90$ of the criminals stated that the crime that caused them being put into prison before the interview wasn't their first crime. While some of their crimes were unveiled, some of them couldn't be. In this research, $\% 92$ of criminals stated that their previous crimes weren't discovered. Similarly, criminals had been taken into custody and arrested many times before. $\% 72$ of criminals said that they had been put into prison more than once. The highest ratio among these was "being put into prison three times". These findings show that a significant amount of criminals commit crime very often, so their criminal tendencies can be very high. Another finding about high criminalization levels is that these people usually have a long history of crime. $\% 80$ of criminals with whom the interviews were made said that they had been committing crimes for 4 or more years. When these findings were evaluated together with the other findings, it was understood that criminals in scope of this research had a lot of experience in their criminal careers; they reinforced criminal tendencies, so it became very difficult for them to stop committing crimes.

$\% 48$ of criminals, with whom interviews were made, stated that they had started their criminal careers only with the crime of burglary and $\% 26$ of them stated that they had started burglary besides other crimes (snatching/hijacking, pick-pocketing, wounding). But later on, besides the crime of burglary, they committed other crimes more and more; namely $\% 20$ of them (10 criminals) only committed the crime of burglary. It was determined that $\% 80$ of the criminals (40 criminals) had committed different crimes besides burglary. The crimes that were committed the most besides burglary were snatching, hijacking, pick-pocketing, drugs and wounding. It was also determine that only $\% 54$ of the criminals of the interview were in the prison only because of the crime of burglary. Although $\% 44$ of the criminals in prison was punished from other crimes besides burglary, generally almost $\% 20$ of criminals had previously been put into prison only because of burglary. In other words, only $1 / 4$ of criminals, with whom the interviews were made, had been put into prison only because of the crime of burglary during the period starting from their first crime until the last crimes they committed, which were the reasons why they were in the prison during interviews. When these findings were evaluated generally, it was seen that people who commit the crime of burglary aren't content with this crime, and commit other crimes, this determination shows that thieves also commit other crimes, and we can understand which kind of crimes they commit mostly besides burglary. These crimes are mostly towards economic earning such as snatching/hijacking, pick-pocketing and selling drugs.

In the light of what burglars told, it was determined that as punishment for burglary was increased and it became difficult to commit the crime of pick-pocketing (reasons such as security team application, people do not carry money in their bags, they are more careful while taking money from banks or are more careful in exchange offices) there has been a decrease in these crimes.

Another significant finding determined in this study is that some criminals who commit the crime of burglary tend to sell drugs in future. The primary reason of this is that; punishment for burglary increased, they are known by policemen as they were arrested or taken into custody before, they become older, many people started burglary, deterrence created by some precautions taken in order to prevent burglary, experience in crime and increase in crime career, and expectation of gaining more money through drug traffic.

Another finding of the research is about the tendency of criminals towards violence. It is significant that $\% 60$ of burglars stated that they used to carry hack and wounding tools (like gun and knife). 7 out of 30 criminals (\%23.3) stated that they used to carry guns while 23 (\%76.7) stated that they used to carry knives. They said that the reasons why they carry guns were; to protect themselves, to scare people who want to stop the ones who try to stop or catch them or to make people do what they do. But it can be said that most of the people who commit the crime of burglary do not have the tendency to use guns against crime victims. $\% 86$ (43 criminals) of 


\section{F.Ü. Sosyal Bilimler Dergisi 2015-25/1}

criminals with whom interviews were made stated that they had never used knife or gun in the houses from which they had stolen something. Only \%14 (7 criminals) said that they used these tools in order to wound or kill.

\section{RESULT AND GENERAL EVALUATION}

This study demonstrated that the following factors were effective in criminalization of the individuals:

- Family problems,

- Economic problems,

- Children working the streets,

- Contact and company of children exhibiting criminal and deviant activities on the street and in the neighborhood,

- To gain the habit of substance abuse,

- Inability to integrate with the basic mission of the school, dropping out of the school,

- Decline of informal supervision,

- The aspirations created by the means older individuals who live by stealing have.

When the profiles of criminals were generally evaluated, it was seen that; they started crimes at very early ages, they lived in areas where poor or low-income families live, they had a low education level and a significant amount (\%66) of them had been dismissed from school during their education lives. When variables about family were analyzed, it was seen that; they had large families and many siblings, they had low-income families, almost $1 / 3$ of them came from families who had migrated, and an important percentage of their fathers had low-qualified jobs such as small business ownerships or day works. Similarly, it was determined that almost none of their mothers were working. It was also determined that an important amount of children (\%74) worked on streets for money in order to support their families, almost $1 / 5$ had broken families (because of the death of one of the parents or divorces), and an important amount of criminals (\% 44) stated that the effect of their family members (especially father and siblings) was important in their lives as criminals. Another significant finding is that almost $1 / 3$ of criminals said that there were other criminal/criminals in their families (father and siblings). On the other hand, an important percentage of criminals said that they didn't go to their houses regularly (\%86) and \%44 said that they had left their houses before they went into prison.

Other significant determinations about the act of crime can be explained as: It was determined that the crime of burglary emerged through an interaction with friends or peers and in a group. An important percentage of criminals $(\% 92)$ stated that people that they spend time together were criminals just like them and similarly an important percentage of criminals (\%94) committed criminal activities "with their friend groups". It can be said that in the formation of tendency towards crime, pretension to known individuals on streets is relatively effective. Another finding is that almost all of the criminals (\%98) had used drugs before they went into prison. Almost 1/3 (\%34) criminals mentioned that they had used drugs during their crimes. More than half of the criminals $(\% 60)$ said that they had carried knives while a small part of them said that they carried guns. Similarly, a small part of them (\%14) said that they used violence while committing crime. A big part of criminals (\%92) said that they had committed crimes which couldn't be unveiled and $\% 72$ of them said that they had gone into prison more than once. These ratios show that repetition among criminals is high. It was determined that criminals, with whom the interviews were made, generally started their criminal lives with burglary and they started to commit different crimes in time (snatching/hijacking, pick-pocketing, drug, wounding). \%76 of criminals said that they committed different crimes besides burglary and they went into prison before. This shows that a significant ratio of people who committed the crime of burglary do not focus on only one type of crime.

As mentioned before, economic level of criminals' families are generally very low, and this 
fact can be seen as an effective factor in understanding their criminal tendencies; namely, economic problems force children into earning money at very early ages and support their families. \%76 of children stated that they worked on streets in order to earn money, and this situation supports this determination. The fact that children spend most of their time on streets increases the possibility of their meeting with criminal people. This means having tendency and imitating successful criminals. A significant ratio of the criminals mentioned in this research stated that they started committing crimes when they wanted to be like other criminals on street; this proves the existence of the fact that streets are significant places that direct children towards crime.

It is an understandable situation for children, who live in a deep poverty, who feel responsible for economic support to their families and so spend time on streets for working, get interested in earning money more easily and have serious interest in criminals who seem to have a good career; because these negativities ease perceiving crime as normal and acceptable. This fact is very important as it gives an idea about the legality bases of the culture of burglary.

In Diyarbakır, there are a lot of children who spend a lot of time either in order to support their families economically, or to be with their friends, so it is a high probability that they meet criminals or members of crime gangs on streets. Earnings they get from criminal acts and opportunities they have create an encouraging effect on children. Especially their cars, motorcycles, the latest cell phones, and beautiful things they wear create a view that they are able to get everything that poor children want. It is difficult for these children, who want to be like these criminals, to guess what these criminals do to get to this point.

In the formation of tendencies towards criminal acts and involving in them has a very "central" role. Shaw and McKay (2006: 97) say that in areas where people, who have lower economic level live, both children who have a poor life and criminals/crime gang members spend time together, so children who see these criminals that have a lot of money and use the latest cars want to have the same life with them.

There is a close relation between the imitation of criminal individuals and the profile of criminals. Especially in the areas where poor families live, criminals or members of crime groups looks like rich people in order to affect children. This situation necessarily creates and interest and desire in children. In frame of this, many children commit the crime of burglary by thinking that they will have a luxurious lifestyle and a lot of money. This means that children want to have opportunities (such as money, clothes, car or motorcycles) which they won't be able to have unless they commit crime. In the interviews, most of the criminals stated that they started committing crimes with this reason.

Providing basis for criminal culture in specific residential areas, where traditional values are weak and poverty exist, is easier. Some children who don't get pocket money from their parents and think that earning money is difficult believe that they can easily have a lot of money through burglary, and this eases their transformation into criminal individuals. Children, who live in residential areas, where criminal values and cultural codes are common, informal control is weak and parents don't have sufficient education and equipment, have the basic thought that they can build their futures by committing crimes which is the basic reason why they enter into criminal lives.

It is very significant that most of the criminals were dismissed from schools. Children who are out of control both in terms of family and school have a high potential to communicate with criminal individuals. As it is difficult to control a child who is dismissed from school, it becomes easier for him/her to meet criminal individuals. This is why, school factor is very important in determining the reasons of criminalization processes and preventing them.

Almost $1 / 3$ of criminals, with whom interviews were made, stated that their families had migrated from other places; this shows that migration dynamics is also important in understanding the fact of crime. In addition to this, problems about family, economy and social values that are 


\section{F.Ü. Sosyal Bilimler Dergisi 2015-25/1}

discussed in this research in terms of research population -in a way- can be discussed in frame of problems created by migration. Socio-economic problems emerging with settlement mobility destroys social organizations and values and weakens social control. Weakening of the control of parents on children is in parallel with the decrease in the meaning and value of family. This situation cause children question the authority of their parents. As a result, it becomes impossible for parents to control their children who live in areas where traditional values start to lose meaning and having no rules or having criminal values become common norms accepted on streets. It is obvious that children, live in the spiral of violence, migration and poverty, socialize by becoming more disposed to crime.

Especially there are very few positive role models that will affect children in disorganized settlements. In these places, crime is like an infectious disease and it can infect other individuals and spread easily. For children who live in poor places, where traditional values and control is weakened, parents don't have enough conscience or knowledge, criminal values exist as common codes, the most reasonable way to "save their lives" or "build their future" is to commit crime or joining gangs.

Individuals learn the values of criminality and crime techniques in crime groups. According to Cloward and Ohlin, who explain burglary with "criminal sub-culture", this crime-sub-culture emphasize financial gain and is based on an economic income that motivates people in order to earn money through short and illegal ways. This is why, according to them, people who commit the crime of burglary are in search of a rational economic income. Cloward and Ohlin state that occupational success develops in a mentor system and criminals see crime as a career/profession. On the other hand, according to Cloward and Ohlin, the most appropriate areas for the emergence of crime sub-cultures based on economic income are settlements where especially legality and illegality are in interaction and connection, mentor system exist among people at different age groups and people transfer their knowledge and experience to one another (Cloward and Ohlin, 1960:161-184). It is possible to say that some areas in Diyarbakir answer to this description.

It was determined that people who commit the crime of burglary had started burglary at very early ages and this became their profession. It can be said that children who commit crime at early ages have bigger potential to commit crime again and their criminal carriers are long. In light with this determination, it should be pointed out that an effective struggle with this crime type is possible only through an early intervention. Children, who have a tendency to crime, who don't have a positive socialization process and fail in behaving properly according to social value and organizations, have chronic criminal behaviors and it becomes more difficult to prevent this situation. This is why; it is more probable to prevent children from becoming criminals by intervening child's antisocial structure early. Besides the fact that during childhood, getting arrested or being sentenced aren't deterrent, getting out of prison without solving any problems that cause their criminal behaviors will not also do any good for children. In our country, it very important to increase medium organizations especially for preventing children from going back to crime environments and criminal friend groups and it is important to make some works with families.

In detailed interviews with individuals who commit the crime of burglary, it was seen that the most important factors in their becoming criminal individuals are family and peer /friend group. This is why, in understanding criminal structures of individuals who commit the crime of burglary, the organization of family should be seriously discussed. So, in the works of preventing criminal tendency and criminal behavior, family-based works should be emphasized.

The most important familial culture that effect criminalization of individuals is the existence of a criminal individual in the family. Almost $1 / 3$ of criminals stated that there was criminal individuals/individual, which is a very significant finding in this research. Existence of a criminal individual in family (especially father) can be effective in directing other family members towards crime, because family members affect one another and children want to imitate the other family 
members. All in all, the act of crime is a learned behavior. Especially in family environments where frequency of close contact and relations is higher, existence of a criminal individual is a serious criminality risk factor. Besides this, as having a criminal father cause emergence of domestic discontent more, it can be said that such negative environments have more serious affects on children. In a way, it can be predicted that negativities resulted from father's criminal behavior can have the function of criminalizing children.

In the interviews, most of the criminals mentioned that especially during being taken into custody and being arrested, their families weren't aware of their crimes. On the other hand, it is thought that the fact that the criminals didn't go to their homes when they started committing crimes was effective in increasing their criminalization level; because, of this situation, criminals can not be controlled by their families which ease their criminal activities. Families' unawareness of their children's crimes also means that they are not sufficiently interested in their children and they don't keep eye on them. When the period between starting crime and being arrested gets longer, the chance to be successful in the interventions, made in order to end crimes, decreases. It can be said that some negative views mentioned by criminals such as domestic problems (shattering of family, poverty, lack of interest etc.) can be effective in their tendency towards spending time out of their houses.

When what individuals told about their start committing crime was analyzed, it was understood that they had started this life after meeting children/young people in their neighborhood. The concept of pretension has a central role in individuals' tendency towards crime. It is possible to say that there is a relation between pretension towards criminals and their images; there lays attraction created by money and statue that will be gained at the basis of pretension.

Most of the answers of criminals to the question of how they started committing crimes are related with their contacts and interactions with their peers and family groups. Relation or cooperation with criminal peers is not only significant in terms of the start of criminal acts, but also in terms of continuing them. This is why, in order to stop criminal behaviors, it is very important to end the relations with criminals besides the fact that peer or friend groups' environments are the places where criminal behaviors are learnt, in such environments, crime becomes to be accepted as legal and it is rationalized. Especially crime sub-culture experienced in such environments are motivational and intensifier for criminal behaviors.

The fact that almost all of the people who commit the crime of burglary have the habit of taking drugs shows that drugs are a significant element of criminal life style. Criminals said that the kind of drug they used the most was marijuana. No doubt, drugs accelerate and ease committing crimes. Use of drugs or alcohol by criminals who commit the crime of burglary is a significant element that determines the density and violence level of their criminal acts.

In this study, findings especially about drugs and the factor of peers can be explanatory in the process of becoming criminals. Generally delinquent peer effect is a determinant for children who have problems with their families and whose connections with families are weakened. When research findings are overviewed, it is seen that factors that are effective in individuals' tendency towards crime are related to one another. For example children who have problems at home or grow in poor families spend more time on streets; and children who spend a lot of time on streets meet criminal or delinquent individuals, start using drugs or start stealing some small things. Children who have the tendency towards crime start to have more problems with their families and this make them unwilling to go home and finally they stop going home. These children who don't go home become more criminal among their peer groups. This explanation shows that in the process of individuals' transforming into criminals; factors such as family problems, poverty, school, peer group and drug use are effective. But it can not be said that experiences of all of the individuals that commit the crime of burglary are formed in this way. Probabilities of meeting criminal and delinquent individuals on streets, hindering school lives, start taking drugs or stealing small things are higher when children spend a lot of time on streets. Children who enter into such a 


\section{F.Ü. Sosyal Bilimler Dergisi 2015-25/1}

delinquent or anti-social structure start to have more problems with their families and they become more unwilling about going to their houses. For some criminals, this unwillingness can sometimes end with completely quitting going home; and these children become more criminal in peer groups. When views of criminals on this issue were generally analyzed, it was understood that factors such as family problems, poverty, school, peer group and drug use are effective together on the process of forming of criminal behaviors. But surely it is impossible to say that criminalization experience of all of the individuals who committed the crime of burglary is formed in this way.

The basic motivation of the crime of burglary is the expectation for financial gain. Most of the criminals said that the most important reason why they firstly committed crime was "the dream of having a lot of money and being rich" and the second important reason was "the wish to imitate friends and their suggestions". But the reason why they continued crimes later on were "financial gain" (such as having a lot of money, being rich), "relations with friend group", "having money sufficient for doing whatever they want, buying whatever they wish" and "forming burglary as a habit". When the factors mentioned by the criminals about the reasons why they continues criminal acts after committing crime for the first time were compared, it was seen that factors of "financial gain" and "friends" interchanged and factor of "habit" became prominent. Factors of "friend/ peer" and "habit" were effective in continuing committing crime can be a seen as a sign that symbolizes reinforcing of criminal structures. These determinations show that although committing the crime of burglary was caused by economic problems or some necessities, continuing burglary later on is caused more by the wish to continue having enough money for luxurious life. In other words, while people start burglary for economic reasons, they may continue it in order to meet their needs of entertainment, gambling, alcohol and drugs. This is why; under the wish for having money, there may not be the wish for meeting the basic needs; criminals may also need money in order to continue their lifestyles based on entertainment and lots of expenses.

The existence of variables such as the poverty of the families and unemployment, the fact that the children had to work the streets to earn small stipends, the possibility of their contact with criminal individuals and crime values on the streets, the damage caused by years of violence and conflict on the values, weakening of social supervision, social disintegration due to migration and the consequences created by it, and the prevalence of crime values in the regions where this study was conducted, could enable the predication of hypotheses of social learning, sub-culture, social control, strain and social disorganization theories in explanation of the criminalization processes of individuals in this study.

However, this study did not scrutinize the crime/opportunity correlation. Further studies could investigate the effects of the existence of opportunity on the creation of criminal motivation for the individual. Because, there are several studies showing that house burglaries are predominantly crimes of opportunity (see: Cohen and Felson, 1979; Kennedy and Forde, 1990; Koening and Linden, 2004)

\section{REFERENCES}

Adler, Freda, Gerhard O.W. Mueller et al. (1995), Criminology, USA: McGraw-Hill

Bohm, Robert M. (1997), A Perimer on Crime and Delinquency, USA: Wadsworth Pub.

Cloward, R. A. and Ohlin, L.E. (1960), Delinquency and Opportunity: a Theory of Delinquent gangs. New York: Free Press

Cohen, Albert K. (1955), Delinquent Boys: the Culture of Gang. New York: Free Press.

Cohen, Lawrence and Marcuse Felson (1979), "Social Change and Crime Rate Trends: A Routine Activity Approach “, American Sociological Review, 44 (4): 588-608

Ellis, Lee, Anthony Walsh (2000), Criminology: A Global Perspective, USA: Allyn and Bacon

www.egm.gov.tr. 
Hirschi, Travis, (1969), Causes of Delinquency, Berkeley: University of California Press.

Kennedy, Leslie and D. Forde (1990). "Routine Activities and Crime: An Analysis of Victimization in Canada." Criminology 28(1):137.

Keyder, Çağlar and Nazan Üstündağ (2006), "Doğu ve Güneydoğu Anadolu'nun Kalkınmasında Sosyal Politikalar”, Doğu ve Güneydoğu Anadolu'da Sosyal ve Ekonomik Öncellikler içinde, (Prepared by: Orhan Kurmuş et al.) Ankara: Açık Toplum Enstitüsü Publications

Kızmaz, Zahir and Rıfat Bilgin (2012), Hırsızlık: Suçlular, nedenler ve Dinamikler, Ankara: Polis Akademisi Yay.

Koening, Daniel J. and Rick Linden (2004) "Conventional or "Street" Crime. Criminology: A Canadian Perspective içinde (ed. R. Linden, 408-43) Toronto: Thomson-Nelson.

Kudat, Ayşe, Ece S. Kılıçözlü et al. (2006), "Doğu ve Güneydoğu Anadolu'nun Kalkınmasında Yatırım Politikaları", Doğu ve Güneydoğu Anadolu'da Sosyal ve Ekonomik Öncelikler içinde (Prepared by Orhan Kurmuş, Ayşe Kudat et al.), Ankara: Açık Toplum Enstitüsü Publications

Matza, David and Sykes, G.M. (1957), "Techniques of Delinquency: A Theory of Delinquency" American Sociological Review, 22 (6): 664-670

Merton, Robert K. (1968) Social Theory and Social Structure, (extended new publication) New York: Free Press

Miethe, Terance D. and David Mcdowall (1993), "Contextual Effects in Models of Criminal Victimization “, Social Forces 71: 741-759

Miller Walter B. (1958), "Lower Class Culture as a Generating Milieu of a Gang Delinquency”, Journal of Social Issues 14: 5 -19

Özgenç, İzzet (2005), Türk Ceza Kanunu Gazi Şerhi, Ankara: Seçkin Pub. (2 ${ }^{\text {nd }}$ Publication)

Polat,Cevdet, Hakan Eren ve Ferdi Erbakıcı (2013), "Hırsızlık Suçunu Etkileyen Faktörlerin Değerlendirilmesi ve Geleceğe Yönelik Yaklaşımlar”, Güvenlik Bilimleri Dergisi 2 (1): 1-33

Seddon, Toby (2000), Explaining the Drug- Crime Link: Theoretical, Policy and Research Issues, Jonl. Soc. Pol.29, 1, 95-107, United Kingdom, Cambridge Univ. Press.

Sampson, Robert J. ; Raudenbush, Stephen W.; Earls Felton (1997). "Neighborhoods and Violent Crime: Multilevel Study of Collective Efficacy," Science, New Series Vol. 277, No. 5328 pp. 918-924

Shaw, Clifford R. and Henry D. Mckay (2006), "Juvenile delinquency and Urban Areas", In Criminological Theory: Past to Present -Essential Readings (Edit.: Francis T. Cullen and Robert Agnew), (Third Edition) Los Angeles, California: Roxbury Publishing Company, PP. 95-101

Sutherland, Edwin. H. (1947), Principles of Criminology, Philadelphia: J.B. Lippincott

Uğurlu, Halil İbrahim (2010), Hırsızlık Suçu (The crime of burglary), Ankara: Adalet Pub.

Yükseker, Deniz (2006b), "Yerinden Edilme ve Sosyal Dışlanma: İstanbul ve Diyarbakır'da Zorunlu Göç Mağdurlarının Yaşadıkları Sorunları”, Zorunlu Göç ile Yüzleşmek: Türkiye’de Yerinden edilme Sonrası Vatandaşlığın İnşası içinde, p.216-233 İstanbul: TESEV Publication.

Vito, Gennaro F., Ronald M. Holmes (1994), Criminology, Theory, Research and Policy, Belmont/ California: International Thomson Pub.

www. tuik.gov.tr (2013), İl Bazında Temel İşgücü Göstergeleri, http://www.tuik.gov.tr/PreHaber Bultenleri.do?id $=15882$

www.tuik.gov.tr. Seçilmiş Göstergelerle Diyarbakır, http://www.tuik.gov.tr/ilGostergeleri/iller/ DIYARBAKIR.pdf 
